Jurnal Manajemen Teori dan Terapan | Tahun 2, No.1, April 2009 | Nanis Susanti

\title{
ANALISIS IMPLIKASI KEPUASAN PELANGGAN TERHADAP PERILAKU PASCA PEMBELIAN MELALUI TESTIMONI DALAM SITUS PEMASARAN INTERNET
}

\author{
Nanis Susanti \\ Ketua Jurusan Manajemen Fakultas Ekonomi Untag Surabaya
}

\begin{abstract}
Abstrak
In global market area, not only marketing concept we have to do, but also applied marketing technology. Getting the service quality is doing by not only physical meet among the customer and service provider, such as convensional market system. In modern community there are like to be faster and instant, time limited is the reason for customer to shopping in the recent system. By the modern marketing system with applying internet technology, called Internet Matketing, the time constraint be minimized. The modern marketing system will closer the distance within the customer and departement store, evertheles just in home shopping. A satisfied customer will recomended their experience to their community, in both on line community or face to face. Studying and analyzing online store net work Zappos.com generate the importance factors for customer satisfaction that will be impact to post purchase behavior. Descriptive analysis using data base of testimony have been eksplore, there are importance factors: product quality, service quallity. That mean testimony is guidance to the other online store how hearing the voice of customer.
\end{abstract}

Keywords: internet marketing, product quality, service quality, customer satisfaction, post-purchase behavior, testimony

\section{Pendahuluan}

Pasar adalah tempat bertemunya penyedia barang dan jasa dengan calon pembeli untuk bertransaksi jual dan beli. Terminologi tempat pertemuan tidak harus secara fisik demikian pula interaksi pertemuan tidak harus tatap muka seperti yang ditemui pada pemasaran konvensional atau tradisional. Perkembangan tehnologi telah memberikan alternatip tempat dan cara bertemu antara penjual dan pembeli bahkan cara pembayaran. Tehnologi Internet membawa dampak revolusioner bagaimana proses pemasaran dilakukan. Internet Marketing tidak membutuhkan bangunan gedung atau toko untuk memajang produk dan menyiapkan jasa, bangunan fisik ini tergantikan oleh web site yang online 24 jam sehari sepanjang tahun, hal yang tidak dapat dilakukan pada Offline marketing dengan keterbatasan waktu dan keharusan tempat secara fisik.

Dalam Pemasaran Internet, web site dari online store dapat didisain secara efektip sehingga memungkinkan calon pembeli untuk browsing dan melakukan proses pembelian secara online: memilih barang dari gambar atau photo produk, lengkap 
dengan deskripsi dan harga serta cara pembayaran dan cara pengiriman. Semua hal ini mungkin terjadi karena informasi yang dibutuhkan untuk proses pembelian dapat dihadirkan secara digital pada web site.

Dalam era global dengan tingkat persaingan yang sangat ketat, fungsi pemasaran harus fokus kepada pelanggan, yang bertujuan untuk menciptakan kepuasan pelanggan. Pelanggan yang puas akan melakukan pembelian ulang dan merekomendasikan pengalamannya kepada komunitas keluarga, teman atau kelompok sosial, berarti pelanggan yang puas adalah aset untuk keberlangsungan usaha.

Untuk menilai kinerja perusahaan terhadap kepuasan pelanggan, pada pemasaran tradisional biasanya disediakan kotak saran, pada pemasaran internet lebih dikenal dengan fasilitas review atau testimoni. Dengan fasilitas testimoni, perusahaan dapat menemukan keunggulan yang akan digunakan sebagai senjata memenangkan pasar, atau kekurangan yang akan diperbaiki.

Peneliti tertarik untuk melakukan analisis kualitatip atas data base testimoni dari Zappos.com untuk produk fashion sepatu/sandal dengan perumusan masalah: "Faktorfaktor kepuasan apakah yang mempengaruhi perilaku pelanggan pasca pembelian pada on-line store Zappos.com".

Selanjutnya tujuan penelitian ini adalah untuk mengetahui faktor-faktor kepuasan pelanggan yang mempengaruhi perilaku pembelian dalam pemasaran internet melalui fasilitas testimony.

\section{Kerangka Teoritis}

\section{Internet Marketing}

Pemasaran internet tidak tergantung tempat dan waktu, fungsi front office yang melayani kedatangan konsumen pada pemasaran tradisional yang selama ini digunakan digantikan oleh situs web. Dalam pemasaran tradisional, tempat dan waktu sangat dibutuhkan untuk mendisplay produk, pemanfaatan space untuk promosi dan publikasi atau sosialisasi produk atau jasa terbaru, dibutuhkan sejumlah sumber daya manusia untuk pelayanan tatap muka, berkomunikasi dan bertukar informasi secara langsung dengan konsumen, pembayaran, pengaduan. Dalam web site, kebutuhan 
untuk aktifitas tersebut dapat dipenuhi tanpa harus menyediakan tempat secara fisik dan tanpa ada batasan waktu dalam hari dan jam sepanjang tahun, semua bauran pemasaran dideskripsi secara digital.

Teknologi Web yang terintegrasi di Internet memainkan peran yang sangat penting, yaitu memungkinkan organisasi/perusahaan memasuki pasar dengan cara yang mudah, murah dan tanpa batasan geografis, semuanya akan berada dalam apa yang dinamai ruang maya (cyberspace). Dalam hal ini organisasi/perusahaan kita akan bersaing dengan organisasi/perusahaan lain di dunia maya (virtual world) (Nugroho 2006: 3)

Tujuan dari perdagangan adalah menjual barang atau jasa untuk menghasilkan laba bersih, yaitu pendapatan setelah dikurangi harga pokok dan biaya-biaya operasional. Dengan tergantungnya tempat dan waktu pada pasar tradisional maka biaya-biaya untuk investasi pada space ruang atau bangunan secara fisik dan panjangnya jalur distribusi menyebabkan biaya operasional tidak dapat ditekan. Demikian pula dari sisi konsumen, sebelum melakukan pembelian, terlebih dahulu harus menemukan tempat-tempat penjualan, melakukan pembandingan harga, dengan mobilitas dari satu tempat ke lain tempat.

Pemasaran Internet mampu memangkas biaya-biaya operasional, karena jalur distribusi diperpendek, seluruh informasi pesanan disimpan dalam sebuah server, konsumen dapat berinteraksi secara langsung tanpa terhalangi jarak dan waktu, order dapat dipenuhi langsung dari tempat usaha atau oleh para supplier, bahkan untuk pelayanan lokal dapat dilakukan pengiriman langsung oleh customer service atau tim layanan pelanggan door to door.

Dengan fleksibilitasnya, perdagangan elektronik dapat memangkas biaya-biaya pemasaran dengan kemudahannya dan kecanggihannya dalam menyampaikan informasi-informasi tentang barang dan jasa langsung ke konsumen di manapun mereka berada (tidak terbatas oleh jangkauan geografis perusahaan) (Nugroho 2006: 8)

Selanjutnya keuntungan perdagangan elektronik

keuntungan bagi perusahaan: memperpendek jarak, perluasan pasar, perluasan jaringan mitra bisnis, efisien. Keuntungan bagi konsumen: efektif, konsumen dapat memperoleh informasi tentang produk/jasa yang dibutuhkannya dan bertransaksi dengan cara yang cepat dan murah; aman secara fisik, konsumen tidak perlu mendatangi toko ... (Nugroho 2006: 20-22)

On-line store adalah salah satu bentuk pemasaran internet, yang merupakan wujud 
maya dari sebuah departemen store. Seluruh bauran pemasaran, product, price, place dan promotion disajikan secara digital dalam sebuah situs web yang terintegrasi dalam internet.

\section{Product Quality}

Rencana strategi untuk menentukan kualitas sebagai prioritas bersaing utama harus berdasar pada beberapa difinisi operasional dari kualitas. Definisi secara umum dari kualitas adalah pemenuhan atau lebih harapan konsumen. Kualitas yang dirasakan sangat berhubungan dengan tingkat kepuasan konsumen. Jika kualitas produk yang diterima lebih rendah dari yang diharapkan, konsumen akan kecewa, demikian pula jika kualitas produk yang dirasakan melebihi yang diharapkan maka konsumen akan sangat puas. Sedangkan secara spesifik definisi kualitas adalah sebagai berikut:

1. Conformance to spesification (kesesuaian dengan spesifikasi/rincian) konsumen berharap barang/jasa yang dibeli dapat memenuhi atau lebih gambaran produk (seperti yang diiklan kan). 2. Value (nilai) seberapa baik produk/jasa menyediakan kegunaan yang diharapkan pada tingkat harga yang dibayar. 3. Fitness for use (kenyamanan) seberapa baik barang/jasa mewujudkan kegunaan yang diharapkan; perhatian terhadap segi mekanik barang, atau kesenangan dari jasa yaitu rupa/penampilan dan gaya, daya tahan, dapat dipercaya, pengerjaan dan pelayanan. 4. Support (dukungan purna jual) dukungan terhadap barang dan jasa sering merupakan pertimbangan utama. Dukungan yang baik dapat memperbaiki_kegagalan kualitas disisi lain. 5. Psychological impression (kesan psikologis): suasana, image atau keindahan dapat mempengaruhi penilaian kualitas oleh konsumen. penampilan dan tindakan penyedia jasa yang tidak sesuai akan merusak atau mengurangi usaha terbaik yang telah dilakukan. Kualitas barang sering juga dinilai atas dasar pengetahuan dan kepribadian pemasar; (mewakili kesan produk yang dibeli) (Krajewski dan Ritzman 2005: 197-198)

Dengan mengetahui definisi kualitas secara spesifik, maka dapat ditentukan bauran product yang yang diinginkan konsumen.

\section{Service Quality}

Sejauh mana suatu jasa memuaskan pelanggan dengan memenuhi kebutuhan, keinginan dan harapan mereka (Lovelock dan Wright 2005: 19). Kesenjangan antara pemuasan dan harapan akan membawa dampak terhadap tingkat kepuasan konsumen. Kualitas jasa adalah keseluruhan sikap pelanggan terhadap penyerahan jasa, yang terbentuk dari sejumlah pengalaman jasa yang berhasil maupun yang tidak berhasil (Lovelock dan Wright 2005: 98). 
Dengan memahami kemungkinan penyebab kesenjangan antara pemuasan dan harapan konsumen, selanjutnya perlu dipahami dimensi kualitas yang diharapkan konsumen.

Kesenjangan jasa bukanlah satu-satunya cara pelanggan menilai kualitas jasa. Mereka juga menggunakan lima dimensi yang luas sebagai kriteria. Kehandalan (reliability). Apakah perusahaan dapat diandalkan dalam menyediakan jasa seperti yang dijanjikan, dari waktu ke waktu? Keberwujudan (tangible). Seperti apa terlihat fasilitas fisik, perlengkapan, karyawan, dan bahan komunikasi penyedia jasa tersebut? Daya tanggap (responsiveness). Apakah karyawan perusahaan tersebut senang membantu dan mampu memberikan jasa yang cepat? Jaminan (assurance). Apakah karyawan jasa memiliki pengetahuan yang cukup, sopan, kompeten, dan dapat dipercaya? Empati (emphaty). Apakah perusahaan jasa tersebut memberikan perhatian yang besar dan khusus? (Lovelock dan Wright 2005: 98-99)

\section{Post Purchase Behavior}

Pelanggan yang puas diharapkan memberikan perilaku positip pasca pembelian misalnya melakukan pembelian ulang, melakukan pembelian dalam jumlah lebih banyak, merekomendasikan teman, keluarga, atau orang lain untuk melakukan pembelian yang sama, selalu membicarakan kebaikan produk atau perusahaan yang memuaskannya.

Kepuasan adalah perasaan senang atau kecewa seseorang yang muncul setelah membandingkan antara kinerja (hasil) produk yang dipikirkan terhadap kinerja (atau hasil) yang diharapkan. Jika kinerja dibawah harapan, pelanggan tidak puas, jika memnuhi harapan, pelanggan puas. Jika kinerja melebihi harapan, pelanggan amat puas atau senang (Kotler 2005: 70)

Dalam menentukan tingkat kepuasan pelanggan, terdapat lima faktor utama yang harus diperhatikan oleh perusahaan yaitu:

Pertama, kualitas produk. Pelanggan akan merasa puas bila hasil evaluasi mereka menunjukkan bahwa produk yang mereka gunakan berkualitas. Kedua, kualitas pelayanan. Pelanggan akan merasa puas bila mereka mendapatkan pelayanan yang baik atau sesuai dengan yang diharapkan. Ketiga, emosional. Kepuasan yang diperoleh bukan karena kualitas dari produk tetapi nilai sosial atau self-esteem yang membuat pelanggan menjadi puas terhadap merek tertentu. Keempat, harga. Produk yang mempunyai kualitas yang sama tetapi menetapkan harga yang relatip murah akan memberikan nilai yang lebih tinggi kepada pelanggannya. Kelima, biaya. Pelanggan yang tidak perlu mengeluarkan biaya tambahan atau tidak perlu membuang waktu untuk mendapatkan suatu produk atau jasa cenderung puas terhadap produk atau jasa itu. (Lupiyoadi 2001: 158) 
Kepuasan atau ketidakpuasan pelanggan akan memberikan dampak pada perilaku pelanggan purna pembelian. Pelanggan yang puas akan melakukan pembelian ulang dan mereferensikan produk atau jasa kepada orang lain, pelanggan yang tidak puas akan beralih pada kompetitor.

Dampak tersebut dapat dilihat: bagaimana perilaku pelanggan dalam melakukan pembelian kembali, bagaimana pelanggan dalam mengekspresikan produk yang dipakainya dan jasa yang diperolehnya, dan perilaku lain yang menggambarkan reaksi pelanggan atas produk dan jasa yang telah dirasakan (Lupiyoadi 2001: 160)

Perilaku pelanggan pasca pembelian dapat diukur dengan lima dimensi yang terinci kedalam 13 indikator sebagai berikut:

Loyalty : 1. Membicarakan hal-hal positip kualitas jasa XYZ kepada orang lain 2. Merekomendasikan jasa XYZ kepada orang lain 3. Mendorong teman atau relasi bisnis untuk berbisnis dengan XYZ 4. Mempertimbangkan XYZ sebagai pilihan pertama dalam membeli/menggunakan jasa ... 5. Melakukan bisnis lebih banyak di waktu mendatang. Switch: 6. Melakukan bisnis lebih sedikit di waktu mendatang 7. Mengalihkan bisnis kepada kompetitor karena harga yang lebih baik . Paymore: 8. Melanjutkan hubungan bisnis dengan XYZ walaupun terjadi kenaikan harga 9. Membayar dengan harga lebih tinggi dibandingkan dengan harga yang diberikan kompetitor karena manfaat lain yang diberikan oleh XYZ. External response: 10. Beralih ke kompetitor jika mengalami masalah dengan pelayanan XYZ 11. Mengeluh kepada pelanggan lain jika mengalami masalah dengan pelayanan XYZ 12. Mengeluh/mengadukan kepada lembaga eksternal apabila mengalami masalah dengan pelayanan XYZ. Internal Response: 13.Mengadukan kepada pegawai XTZ jika mengalami masalah dengan pelayanan XYZ (Zeithaml at.al 1996: 38)

\section{Testimonial}

Dalam era globalisasi ini, perusahaan akan selalu menyadari akan pentingnya faktor pelanggan. Oleh karena itu mengukur tingkat kepuasan para pelanggan sangatlah perlu (Lupiyoadi: 158). Tersedianya fasilitas review pada Situs Pemasaran Internet bagi konsumen untuk menyampaikan tinjauan atau penilaian atas pelayanan yang diperoleh dalam transaksi barang atau jasa menunjukkan bahwa hampir semua pemasar menyukai penggunanaan testimonial. Banyak website yang menggunakan taktik ini untuk meningkatkan trend penjualan. Pada Pemasaran off line, fasilitas ini berupa kotak saran, cenderung tertutup dan individual, terbatas saran atau keluhan seorang konsumen pada organisasi penyedia jasa atau produk. Sedangkan pada Pemasaran on line, fasilitas review atau suara pelanggan sangat terbuka, suara konsumen individual dapat dibaca oleh pelanggan lain. "A cursory review of Internet 
marketing sites shows that most marketers favor using testimonials. This is also reflected in the countless websites using this tactic to try to increase leads or sales". (Marketing Experiment Journal, online)

Transparent marketing is a key reason why credibility indicators such as testimonials, when properly used, tend to perform well. On a scale of 1 to 5 (with 5 being the "most effective"), marketers surveyed for the MarketingSherpa Landing Page Handbook rated various types of testimonials among the most effective tactics for improving conversion rates. (Marketing Experiment Journal, online)

Tabel 1

Efektifitas Taktik Pemasaran

\begin{tabular}{|c|c|c|c|c|c|}
\hline $\begin{array}{l}\text { Marketing } \\
\text { Tactic }\end{array}$ & Total & Client & Agency & B2B & B2C \\
\hline $\begin{array}{c}\text { Customer } \\
\text { Reviews }\end{array}$ & 3.5 & 3.5 & 3.6 & 3.4 & 3.6 \\
\hline $\begin{array}{c}\text { Video } \\
\text { Testimonials }\end{array}$ & 3.4 & 3.4 & 3.4 & 3.5 & 3.3 \\
\hline $\begin{array}{c}\text { Audio } \\
\text { Testimonials } \\
\end{array}$ & 2.9 & 2.9 & 2.8 & 2.9 & 2.8 \\
\hline
\end{tabular}

Sumber: MarketingSherpa Landing Page Handbook dalam Marketing Experiment Journal, online

Dari tabel di atas dapat disimpulkan bahwa customer review lebih dapat dipercaya dibandingkan yang lainnya. Format testimoni dalam bentuk teks lebih mudah untuk diperoleh dan ditampilkan. Pemasar membutuhkan testimoni untuk menguji indikator kepuasan pelanggan yang akan diperbaki dan ditingkatkan.

Dengan fasilitas review atau testimoni dapat segera diketahui keluhan pelanggan dan ekspresi kepuasan pelanggan. Substansi Keluhan adalah keinginan konsumen untuk mengetahui masalah yang terjadi pada order, produk, dimana masalah dapat diperbaiki secara cepat dan lengkap tanpa kesulitan. Persepsi Keluhan misalnya kekhawatiran, apa yang dipikirkan ketika konsumen mengalami masalah, yang memungkinkan konsumen merasa diabaikan dan akhirnya menjauh, menuntut waktu yang panjang untuk proses penanganan perselisishan.

Anxiety is defined as a psychological concern stimulated by a given element in the sales process. While anxiety often stems from legitimate concerns, its degree and impact are often disproportionate to the measure of risk. You must address it on two levels: substance and perception. (Marketing Experiment Journal, online) 
Selanjutnya masih berdasarkan Marketing Experiment Journal, online; penyebab umum keluhan pelanggan antara lain: Quality of the product/service, Reliability of the product/service, Credit Card Security, Price: Competitiveness - Can I get it for less elsewhere? Cost/benefit — Is it worth the price for me? Testimonial dapat diharapkan memberikan gambaran tentang 3 hal: timeliness, product quality, and customer satisfaction.

Pencapaian kepuasan pelanggan melalui kualitas pelayanan, dapat ditingkatkan dengan pendekatan antara lain sebagai berikut:

1. Memperkecil kesenjangan-kesenjangan yang terjadi antara pihak manajemen dan pelanggan. Misalnya melakukan penelitian dengan metode customer focus yang mengedarkan kuesioner dalam beberapa periode, untuk mengetahui persepsi pelayanan menurut pelanggan.

2. Memberi kesempatan kepada pelanggan untuk menyampaikan keluhan. Dengan membentuk complaint and suggestion system, misalnya dengan hotline bebas pulsa. (Lupiyoadi 2001: 158)

Untuk mendesain jasa yang memenuhi atau melampaui harapan pelanggan, penyedia jasa harus mengetahui apa yang sebenarnya dialami pelanggan selama mereka menggunakan jasa (Lovelock dan Wright 2005: 85). Dengan fasilitas testimony, pelanggan yang kecewa maupun pelanggan yang puas dapat menyalurkannya secara on-line dan terbuka, karena pelanggan yang lain atau calon pelanggan dapat saling mengetahui. Data base testimoni sangat berguna untuk memperbaiki dan mempertahankan faktor-faktor yang mempengaruhi kepuasan pelanggan.

Pada dasarnya kepuasan dan ketidakpuasan pelanggan atas produk akan berpengaruh pada pola perilaku selanjutnya. Hal ini ditunjukkan pelanggan setelah terjadi proses pembelian (postpurchase action) (Kotler 1997 dalam Lupiyoadi 2001: 159). Apabila pelanggan merasa puas, maka dia akan menunjukkan besarnya kemungkinan untuk kembali membeli produk yang sama. Pelanggan yang puas juga cenderung akan memberikan referensi yang baik terhadap produk kepada orang lain (Lupiyoadi 2001: 159)

Dengan menelaah teori di atas, maka dapat dikembangkan sebuah alur pikir penelitian sebagai berikut: Pemasaran Internet memungkinkan organisasi/perusahaan memasuki pasar dengan cara yang mudah, murah dan tanpa batasan geografis, semuanya akan berada dalam apa yang dinamai ruang maya (cyberspace), dan akan bersaing di dunia maya (virtual world). Zappos.com adalah online store, dengan salah 
satu produk fashion yaitu sepatu/sandal. Produk fashion sangat dipengaruhi oleh selera individual dan perubahan mode, disain, bahan, warna serta skala ukuran (size). Konsumen melakukan proses pemilihan produk dan keputusan pembelian secara online, informasi dan komunikasi dijalin secara digital, maka proses penyerahan barang dan pemenuhan order merupakan kualitas pelayanan yang harus diberi prioritas tinggi. Kepuasan konsumen sangat tergantung pada pembandingan antara apa yang akan diterima setelah melakukan keputusan pembelian dengan apa yang dirasakan setelah proses penerimaan barang. Jika tidak ada kesenjangan di antaranya, maka konsumen akan puas dan sebaliknya akan kecewa. Pelanggan yang puas akan mengekspresikan pengalamannya kepada perusahaan dan kepada orang lain. Saluran untuk mengekspresikan pengalaman secara digital tersedia pada fasilitas testimonial di Web Site. Dari data base testimonial akan diketahui perilaku pelanggan Zappos.com pasca pembelian.

\section{Metode Penelitian}

Obyek penelitian adalah online store Zappos.com dengan mengambil data dari fasilitas testimonial untuk periode Maret 2008. Pengukuran dan analisis data secara kualitatip deskriptip, yang akan menggambarkan ekspresi sesungguhnya dari tingkat kepuasan konsumen. Data kualitatip meskipun tidak terstruktur tetapi lebih bersifat in depth statement. Dari data kualitatip testimonial akan dibuat pemetaan sesuai variabel yang akan diteliti.

\section{Definisi operasional variabel yang diteliti adalah}

Product Quality adalah kualitas produk yang diekspresikan oleh konsumen dalam testimoninya dan akan dipetakan kedalam definisi kualitas sebagai berikut:

1. Conformance to spesification (kesesuaian dengan spesifikasi/rincian), terpenuhinya harapan konsumen atas sepatu/sandal yang dibeli sesuai gambaran produk secara digital dalam web site.

2. Value (nilai), seberapa baik sepatu/sandal menyediakan kegunaan yang diharapkan pada tingkat harga yang dibayar.

3. Fitness for use (kenyamanan) seberapa baik sepatu/sandal mewujudkan kegunaan yang diharapkan

4. Support (dukungan dalam proses pembelian dan penyerahan barang), bentuk- 
bentuk customer support Zappos.com yang diekspresikan konsumen atas penyerahan pesanan sepatu/sandal

5. Psychological impression (kesan psikologis), suasana hati, atau kegembiraan yang dialami konsumen dan mempengaruhi penilaian kualitas oleh konsumen terhadap Zappos.com.

\section{Service Quality}

1. Tangible (bukti fisik), Seperti apa penilaian fasilitas fisik web site yang dikunjungi pelanggan, kelengkapan fasilitas layanan belanja, kelengkapan informasi mengenai produk, harga dan layanan komunikasi yang tersedia.

2. Reliability (kehandalan). Apakah zappos.com dapat diandalkan dalam menyediakan barang seperti yang dijanjikan, ketepatan waktu pengiriman , kesesuaian pesanan.

3. Responsiveness (daya tanggap). Zappos.com selalu siap membantu dan mampu memberikan solusi yang cepat apabila ada masalah dalam pemesanan dan penerimaan barang

4. Assurance (jaminan). Apakah zappos.com memiliki fasilitas komunikasi dua arah yang selalu siap membantu pelanggan dalam memenuhi produk yang dicari , ukuran dan spesifikasi khusus. Bagaimanakah kemampuan customer service dalam mendukung pelayanan kepada pelanggan, kesediaan mendengar dan kesopanan dalam berkomunikasi

5. Empati (emphaty). Apakah customer service memberikan perhatian yang besar dan khusus.

\section{Behavioral-Intentions}

1. Loyality (kesetiaan) : Pelanggan membicarakan hal-hal positip zappos.com kepada orang lain, merekomendasikan kepada orang lain untuk belanja ke Zappos.com, mendorong teman atau relasi bisnis untuk belanja ke Zappos.com, mempertimbangkan zappos.com sebagai pilihan pertama dalam membelisepatu/sandal, melakukan pembelian ulang di waktu mendatang. 
2. Switch (berpindah ke kompetitor) tidak lagi melakukan pembelian melaui zappos.com, mengalihkan belanja kepada on-line store karena harga yang lebih baik .

3. Paymore: tetap berbelanja walaupun terjadi kenaikan terjadi harga, membayar dengan harga lebih tinggi dibandingkan dengan harga yang diberikan kompetitor karena manfaat lain yang diberikan Zappos.com.

4. External response: beralih ke kompetitor jika mengalami masalah dengan pelayanan, mengeluh kepada pelanggan lain jika mengalami masalah, mengeluh/mengadukan kepada lembaga eksternal apabila mengalami masalah

5. Internal Response:.mengadukan kepada customer service zappos.com jika mengalami masalah dengan pesanan atau pelayanan

\section{Metode Analisis Data}

Data kualitatip yang diambil dari data base testimonial akan dipetakan kedalam variabel operasional dalam tabulasi, dan menyimpulkan hasil pemetaan dengan metode analisis statistik deskriptip. Dari analisis tersebut dapat dibuat rangking variabel kualitas produk, kualitas layanan yang mempengaruhi perilaku pasca pembelian, dan perilaku pasca pembelian yang paling dominan.

Untuk keperluan tabulasi dibuat koding untuk setiap indikator yang diteliti sebagai berikut

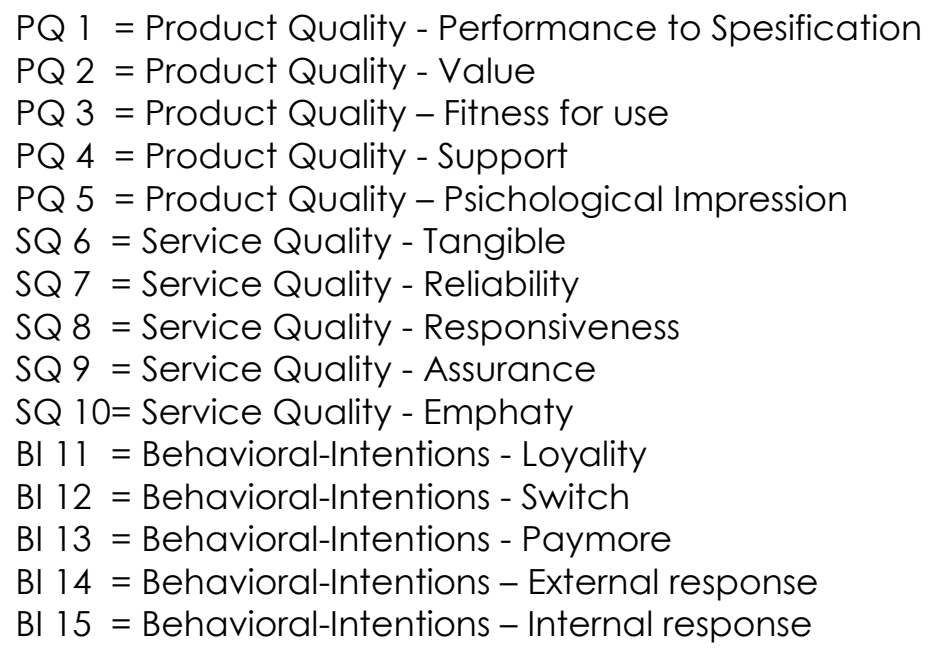




\section{Analisis Data}

Data base testimoni di download dari www.zappos.com untuk periode Maret 2008 (testimoni tanggal 3-17). Tercatat 166 pelanggan yang menuliskan testimoninya secara on line, dan diperoleh 409 kata kunci untuk pemetaan kedam 15 indikator yang diteliti. Tabulasi data dari kata kunci kedalam pemetaan indikator adalah seperti dalam tabel berikut:

Tabel 2

Pemetaan kata kunci

Product Quality

\begin{tabular}{|l|l|l|l|}
\hline \multicolumn{1}{|c|}{ Kata kunci } & \multicolumn{1}{|c|}{ Total } & \% kata kunci & \% dari 166 pelanggan \\
\hline Performance to Spesification & 16 & 11,35 & 9,64 \\
\hline Value & 39 & 27,66 & 23,49 \\
\hline Fitness for Use & 19 & 13,48 & 11,45 \\
\hline Support & 67 & 47,52 & 40,36 \\
\hline Psichological Impression & 0 & 0 & 0 \\
\hline Total kata kunci & 141 & 100 & 84,94 \\
\hline
\end{tabular}

Sumber: data base testimoni Zappos,com, diolah

Dari 166 pelanggan yang memberikan testimoni, $84,94 \%$ menyatakan kepuasannya terhadap kualitas produk, dengan pilihan dimensi paling dominan adalah support (40,36\%) dan value (23,49\%). Pelanggan tersebut mengekspresikan kepuasannya terhadap kualitas produk kedalam 141 kata kunci yang masing-masing dapat dipetakan kedalam lima dimensi kualitas produk. Support $(47,52 \%)$ dan value $(27,66 \%)$ merupakan ekspresi dominan terhadap kualitas produk. Statistik tersebut memberikan gambaran bahwa kepuasan pelanggan atas kualitas produk Zappos.com sangat dipengaruhi oleh dimensi support dan value. Support adalah keberadaan customer service yang kompeten dalam menindak lanjuti data base pesanan dalam server, menangani pemilihan produk dengan spesifikasi khusus, pesanan, pengiriman, termasuk dukungan fasilitas komunikasi dua arah secara online melalui email, dan hubungan telepon langsung. Selain support, value juga sangat mempengaruhi kepuasan pelanggan. Value meliputi harga produk yang wajar, dan lebih penting lagi adalah bebas biaya retur barang dari pelanggan ke zappos.com dan sebaliknya setelah ada penggantian barang dari zappos.com ke pelanggan. 
Tabel 3

Pemetaan kata kunci

Service Quality

\begin{tabular}{|l|l|l|l|}
\hline \multicolumn{1}{|c|}{ Kata kunci } & \multicolumn{1}{|c|}{ Total } & \% kata kunci & \% dari 166 pelanggan \\
\hline Tangible & 8 & 5,44 & 4,82 \\
\hline Reliability & 87 & 59,18 & 52,41 \\
\hline Responsiveness & 23 & 15,65 & 13,86 \\
\hline Assurance & 19 & 12,93 & 11,45 \\
\hline Emphaty Total kata kunci & 10 & 6,80 & 6,02 \\
\hline & 147 & 100 & 88,55 \\
\hline
\end{tabular}

Sumber: data base testimoni Zappos,com, diolah

Dari 166 pelanggan yang memberikan testimoni, 88,55\% menyatakan kepuasannya terhadap kualitas pelayanan, dimensi paling dominan reliability $(52,41 \%)$ dan responsiveness (13,86\%). Pelanggan mengekspresikan kepuasannya terhadap kualitas layanan kedalam 147 kata kunci yang masing-masing dapat dipetakan kedalam lima dimensi kualitas layanan. Reliability $(59,18 \%)$ dan responsiveness $(15,65 \%)$ merupakan ekspresi dominan kualitas layanan. Statistik tersebut menggambaran bahwa kepuasan pelanggan atas kualitas layanan Zappos.com sangat dipengaruhi oleh dimensi reliability dan responsiveness. Reliability adalah keandalan Zappos.com dalam delivery time dan ketepatan pesanan yang diterima, sedangkan responsiveness adalah tanggapan Zappos.com atas permintaan percepatan pengiriman pesanan, atau atas perubahan jadwal pengiriman dari regular ke priority, dan penanganan retur pesanan yang cepat dan tidak rumit.

Tabel 4

Pemetaan kata kunci

Behavioral-Intentions

\begin{tabular}{|l|c|c|c|}
\hline \multicolumn{1}{|c|}{ Kata kunci } & Total & \% kata kunci & \% dari 166 pelanggan \\
\hline Loyality & 121 & 100 & 72,89 \\
\hline Switch & 0 & 0 & 0 \\
\hline Paymore & 0 & 0 & 0 \\
\hline External response & 0 & 0 & 0 \\
\hline Internal response & 0 & 0 & 0 \\
\hline \multicolumn{1}{|c|}{ Total kata kunci } & 121 & 100 & 72,89 \\
\hline
\end{tabular}

Sumber: data base testimoni Zappos,com, diolah 
Dari 166 pelanggan yang memberikan testimoni, 72,89\% pelanggan menyatakan perilaku pasca pembelian yang positip, yaitu loyalitas atau kesetiaannya kepada zappos.com, antara lain berbelanja ulang untuk dirinya sendiri dan anggota keluarga, merekomendasikan zappos.com sebagai tempat belanja sepatu/sandal kepada teman dan selalu membicarakan hal-hal yang baik tentang zappos.com kepada orang lain serta menulis/mengirim testimoni kepuasannya secara on-line.

\section{Pembahasan dan Kesimpulan}

Obyek penelitian Internet Marketing ini adalah online store Zappos.com yang berbasis di California, Amerika. Pada 1999, pendiri Zappos Nick Awinmurn, berkeliling ke sebuah mal di San Francisco, mencari sepasang sepatu. Di sebuah toko ada model yang cocok, tetapi tidak dengan warnanya. Di toko lain ada warna yang cocok, tetapi tidak dengan ukurannya. Nick menghabiskan waktunya di mal, berjalan dari toko ke toko, dan akhirnya pulang ke rumah dengan tangan hampa dan frustasi. Di rumah, Nick mencoba mencari sepatu secara online, dan lagi-lagi tidak berhasil. Meskipun disana ada sejumlah toko sepatu online yang menjual sepatu berkategori "mom and pop", yang menarik bagi Nick adalah bahwa disana tidak ada pengecer online yang khusus menjual sepatu.Maka sejak 1999 itu, dan segalanya menjadi sangat mungkin, Nick memutuskan untuk berhenti bekerja dan mulai membuka usaha retail sepatu, ... lahirlah Zappos.com. Ide aslinya adalah membuat web site yang menawarkan koleksi sepatu dalam hal merek, model, warna, ukuran dan kelonggaran. Mulai sekitar 7 tahun lalu, telah menjadi perusahaan yang menyediakan pilihan-pilihan terbaik tidak saja dalam produk sepatu, tetapi juga dalam berbagai kategori.

Dalam pembelian secara online, kecepatan waktu penerimaan barang merupakan peran yang sangat penting dan mempengaruhi bagaimana konsumen berpikir tentang apakah akan belanja lagi secara online di kemudian hari. Untuk itu Zappos telah siap dengan stock di gudang, item yang belum siap dijual tidak akan ditampilkan dalam web, sampai secara fisik telah siap di gudang. Tujuan Zappos adalah menjadi posisi leader dalam bisnis online, jika pelanggan telah berhasil mempersepsikan Zappos dengan layanan terbaik, maka akan ekspansi kedalam kategori produk lain selainsepatu.Saat ini 
Zappos menangani 500 merek, lebih dari 90.000 model dan memelihara 2 juta pasang sepatu sebagai stock, dengan jumlah pegawai 600 orang. Visi Zappos adalah:

- One day, $30 \%$ of all retail transactions in the US will be online.

- People will buy from the company with the best service and the best selection.

- Zappos will be that company (www.Zappos.com)

Dari 166 pelanggan yang memberikan testimoni, 84,94\% menyatakan kepuasannya terhadap kualitas produk, dengan pilihan dimensi paling dominan adalah support $(40,36 \%)$ dan value $(23,49 \%)$; $88,55 \%$ menyatakan kepuasannya terhadap kualitas pelayanan, dengan pilihan dimensi paling dominan adalah reliability $(52,41 \%)$ dan responsiveness (13,86\%); 72,89\% pelanggan menyatakan perilaku pasca pembelian yang positip. Dapat disimpulkan bahwa zappos.com telah berhasil memuaskan pelangganya, sebagian besar ekspresi menyatakan bahwa kualitas yang diterima dan dirasakan jauh melampaui kualitas yang diharapkan, lebih lanjut pelanggan yang sangat puas menunjukkan loyalitasnya yang tinggi dengan semangat untuk merekomendasikan Zappos.com sebagai pilihan situs belanja sepatu/sandal.

Indikator psichological impression tidak terpetakan, tidak ada responden yang mengekspresikan pengaruh psikologis dalam menilai kualitas produk sepatu/sandal. Hal ini bisa dipahami karena pembelian barang secara on line tidak terkait langsung dengan bukti fisik, misalnya suasana, interaksi langsung dengan sistem penyerahan barang. Pengaruh tersebut akan tergantikan dalam dimensi emphaty dalam kualitas jasa, 6,02\% dari 166 pelanggan mengekspresikannya.

Seluruh dimensi kualitas jasa terpetakan, hal ini menandakan bahwa business on line menempati pasar maya, maka kualitas layanan sangat berperan. Sedangkan untuk perilaku pasca pembelian, hanya loyalitas yang terpetakan, karena seluruh testimoni mengekspresikan kepuasan. Konsumen yang puas tidak akan pindah ke online store yang lain, dan loyalitas yang sangat tinggi tidak perlu megekspresikan paymore sebagai syarat kepuasannya. External response dan internal response adalah upaya untuk mengemukanan kekecewaan kepada pihak luar dan pihak intern. Kedua dimensi ini tidak terpetakan, karena 166 pelanggan yang membuat testimoni telah sangat loyal (72,89\%), berarti mereka tidak mengalami atau menganggap mendapatkan masalah apapun dengan Zappos.com. Dari responsifeness, angka pemetaan cukup tinggi (13,86\%), karena kebijakan Zappos untuk menangani keluhan atau permintaan pelanggan telah dijalankan dengan konsisten. 
Beberapa testimoni yang didownload dari zappos.com dapat menggambarkan ekspresi kepuasan pelanggan dan perilaku pasca pembelian sebagai berikut:

"I just wanted to let you guys know that I have been very pleased with your company. I can't stop telling all of my friends and family about you. Thank you for your excellent customer service and reliability. You guys are the best!" Sincerely, Everett S. Everett S., 2008-03-17

Pernyaaan "I can't stop telling all of my friends and family about you" menunjukkan loyalitas, excellent customer service menandakan kepuasan pelanggan atas kualitas produk yang didukung (support) bagian layanan konsumen, sedangkan reliability adalah kata kunci untuk kualitas layanan.

"Hello!!! We received our shoes today and wanted to thank you sooo much for the expedited (and at no extra charge!) service!!! What a nice surprise to come home to - when we didn't expect them for another 4-5 days! You guys are the best - we'll be doing MUCH more business with you very soon. Enjoy the weekend and many thanks again". Leslie S. Leslie S., 2008-03-17

The expedited (and at no extra charge!) service adalah gambaran untuk kiriman kilat (reliability, kualitas layanan) tanpa tambahan biaya (value, kualitas produk), What a nice surprise to come home to - when we didn't expect them for another 4-5 days! You guys are the best (customer service, kualitas produk)

Thank you so much for shipping my shoes to me so quickly. I love them, they're exactly what I requested in perfect condition, and your service was excellent! In today's world, the quality and service is poor, however, yours is of high quality, high caliber, and you listen to what your customers want. Thank You. Anonymous, 2008-03-17

Pernyataan tersebut memuat ekspresi reliability, conformance to spesification,support, satisfaction. Selanjutnya jika dibuat daftar beberapa ekspresi untuk setiap variabel adalah sebagai berikut:

\section{Product Quality}

1. The item is in good and exactly how I expected it (conformance to spesification)

2. I am always afraid to order shoes online because I can't try them on. With your company's free return shipping policy there is no risk (value)

3. I love my new shoes, there were comfortable from the moment I put them on (fitness for use)

4. Thanks so much. I appreciate your excellent customer service. You have always exceed my expectation (support) 


\section{Service Quality}

1. Not only do you have excellent shipping and return policies, but your site is straightfoward and easy to use (tangible)

2. I can't believe that after I ordered my shoes last night, I return home from work this evening to find them on my doorstep.

3. You all are very prompt in crediting a return. Zappos.com took a pair of shoes back that I had worn - which were very uncomfortable - without any problem (responsiveness)

4. I tend to think that customer service testimonials on website are fake, but I now know that Zappos is serious about cultivating quality customer relatonship (assurance)

5. Thank you, wow what service! Zappos has the best company, All of my questions were answered in a kindly polite manner (emphaty)

\section{Behavioral-Intentions}

1. I will also let people know where to order shoes on line. Zappos.com! (loyality)

2. Your quick shipping and great customer service is why we always come back to Zappos (loyality)

3. I will certainty do more shoe shopping at Zappos ... and look out if I get into the accessories and handbags! (loyality)

4. I thought I would give Zappos a try and now I am happy with warm feet. You have earned a new customer (loyality)

5. I can't wait to get more money and buy more shoes at Zappos (loyality)

Dari pembahasan di atas dapat ditarik kesimpulan penelitian sebagai berikut:

1. Online store sebagai salah satu bentuk Pemasaran internet, harus menempatkan support dan value sebagai prioritas bersaing dalam kualitas produk, selain itu kualitas layanan sangat ditentukan oleh reliabilty dan responsiveness.

2. Dukungan Customer service pada proses pembelian dan efisiensi biaya penyerahan barang, serta kecepatan pemenuhan order dan tanggapan atas masalah yang dihadai pelanggan akan menumbuhkan loyalitas yang sangat tinggi

3. Pelanggan yang puas akan termotivasi untuk memberikan testimoni yang sangat berguna bagi keberlangsungan usaha.

4. Testimoni adalah sarana komunikasi yang efektip dalam menghubungkan pelanggan dengan perusahaan, atau antara pelanggan dengan calon pelanggan 


\section{Daftar Referensi}

Kotler, Philip 2005, Manajemen Pemasaran Jilid 1, Terjemahan Benyamin Molan, Indeks

Krajewski, Lee J., Larry P. Ritzman, 2005, Operations Management, Prentice Hall

Lovelock, Christopher H., Lauren K. Wright, 2005, Manajemen Pemasaran Jasa, Terjemahan Agus Widyantoro, Indeks

Lupiyoadii, Rambat, 2001, Manajemen Pemasaran Jasa, Salemba Empat

Marketing Experiment Journal, online

Nugroho, Adi, 2006, e-Commerce, Informatika

$\underline{\text { www.Zappos.com }}$

Zeithaml, Valerie A, Leonard L. Berry, A. Parasuraman, 1996, The Behavioral Consequences of Service Quality, Journal of Marketing 60 (April): 31-46 
Lampiran: Tabulasi data testimoni pelanggan Zappos.com

\begin{tabular}{|c|c|c|c|c|c|c|c|c|c|c|c|c|c|c|c|c|}
\hline No & Nama & P1 & P2 & P3 & P4 & P5 & s6 & S7 & S8 & s9 & $S 10$ & $\begin{array}{c}\text { B } \\
11\end{array}$ & B12 & B13 & B14 & B15 \\
\hline 1 & Everett $S$ & & & & 1 & & & 1 & & & & 1 & & & & \\
\hline 2 & Anonymous & & & 1 & & & & 1 & 1 & 1 & & 1 & & & & \\
\hline 3 & Leslie S & & 1 & & & & & 1 & & 1 & & & & & & \\
\hline 4 & Anonymous & & & & & & & & & & & 1 & & & & \\
\hline 5 & Anonymous & 1 & & & & & & 1 & & & & 1 & & & & \\
\hline 6 & Anonymous & & & 1 & & & & 1 & & & & 1 & & & & \\
\hline 7 & Anonymous & & & & & & & 1 & & & & & & & & \\
\hline 8 & Marcia & & & 1 & & & & & & & & 1 & & & & \\
\hline 9 & Anonymous & & & & & & & & & & & 1 & & & & \\
\hline 10 & Anonymous & & & & & & & & 1 & & & 1 & & & & \\
\hline 11 & Lynn & & & & & & & & & & & 1 & & & & \\
\hline 12 & Lucy B & & & & & & & & & & 1 & & & & & \\
\hline 13 & Anonymous & & & & 1 & & & 1 & & & & & & & & \\
\hline 14 & Barbara B & & 1 & & 1 & & & 1 & & & & 1 & & & & \\
\hline 15 & Anonymous & 1 & 2 & & & & & 1 & & & & 1 & & & & \\
\hline 16 & Marlene G & & & & & & & & & & & 1 & & & & \\
\hline 17 & Amy C & & & & & & & & & & & 1 & & & & \\
\hline 18 & BNB & & & & & & & 1 & & & & 1 & & & & \\
\hline 19 & Richard S & & & & & & & & & & & 1 & & & & \\
\hline 20 & Anonymous & 1 & & 1 & & & & & & & & 1 & & & & \\
\hline 21 & Anonymous & & & & & & & & & & & 1 & & & & \\
\hline 22 & Anonymous & & & & & & & & & & & 1 & & & & \\
\hline 23 & Richard S & & & & & & & & 1 & & & 1 & & & & \\
\hline 24 & Anonymous & & 1 & & & & & & & 1 & & 1 & & & & \\
\hline 25 & Anonymous & 1 & & & & & & 1 & & 1 & & 1 & & & & \\
\hline 26 & Linda B & & & & & & & 1 & & & & 1 & & & & \\
\hline 27 & Anonymous & & & & & & & & & & & 1 & & & & \\
\hline 28 & Ralph & & & & & & & 1 & & & 1 & 1 & & & & \\
\hline 29 & Carman & & & & 1 & & & & & & & & & & & \\
\hline 30 & Athena & 1 & 1 & & & & & 1 & & & & & & & & \\
\hline 31 & Marylin $\mathrm{H}$ & & & & & & & 1 & & & & 1 & & & & \\
\hline 32 & Laura G & & & & & & & & & & & 1 & & & & \\
\hline 33 & Mary $P$ & & & & 1 & & & & & & & & & & & \\
\hline 34 & Dena G & & 1 & & & & & & & & & 1 & & & & \\
\hline 35 & Judy & & & & & & & 1 & & & & 1 & & & & \\
\hline 36 & Jill B & 1 & & 1 & & & & 1 & & & & 1 & & & & \\
\hline 37 & Anonymous & & & & & & & & & & 1 & 1 & & & & \\
\hline 38 & Katie S & & & & & & & & & & & 1 & & & & \\
\hline 39 & Linda M & & & & & & & & 1 & & & 1 & & & & \\
\hline 40 & Anonymous & & & & & & & 1 & & & & & & & & \\
\hline 41 & Anonymous & & 1 & & 1 & & & 1 & & 1 & & 1 & & & & \\
\hline 42 & Jordan $\mathrm{G}$ & & & & 1 & & & & & 1 & & 1 & & & & \\
\hline 43 & Anonymous & & 1 & & & & & 1 & & & & & & & & \\
\hline 44 & Shilo S & & & & & & & 1 & & & & 1 & & & & \\
\hline 45 & Anonymous & & & & 1 & & & & 1 & & & 1 & & & & \\
\hline
\end{tabular}




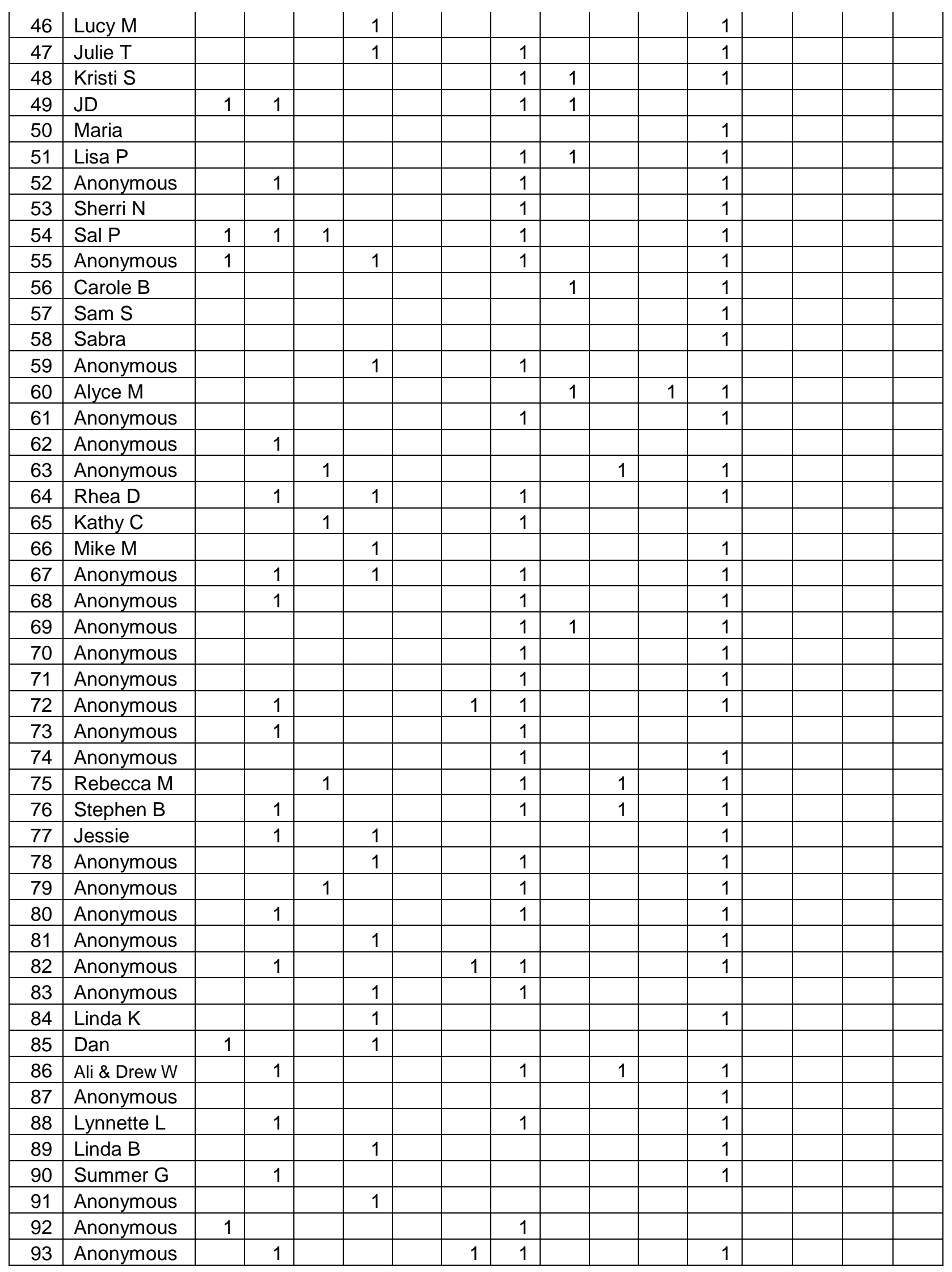




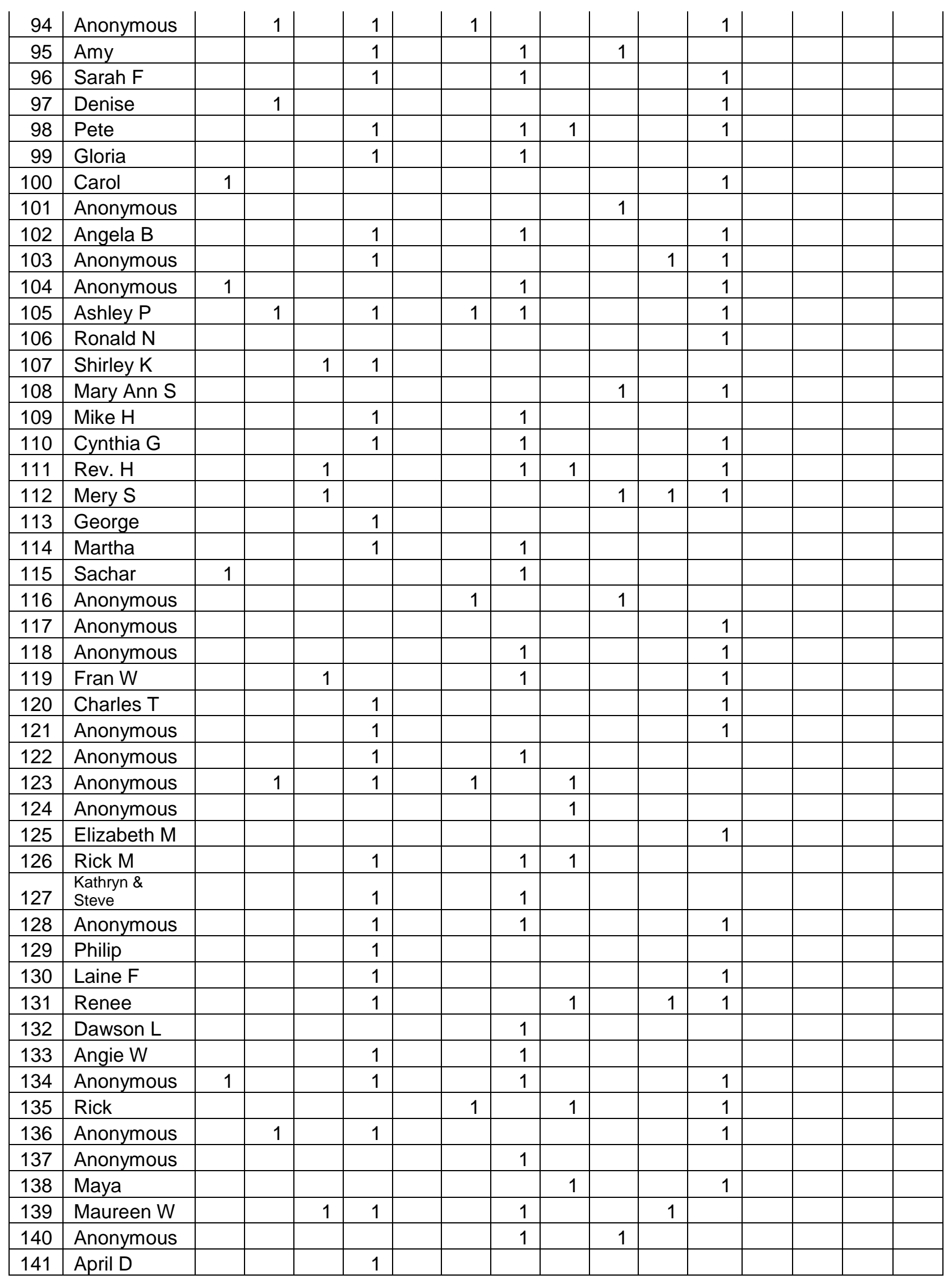




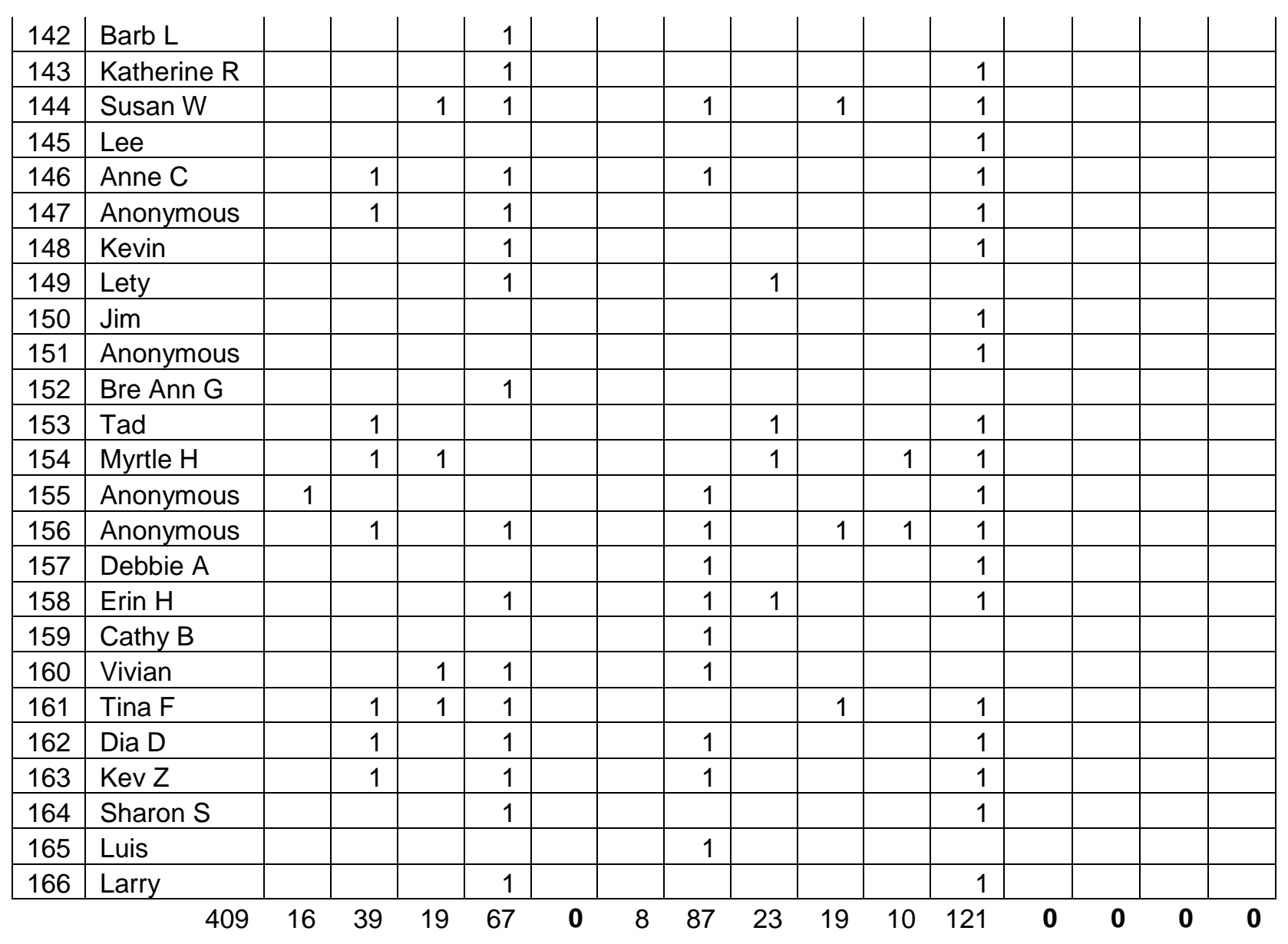


Jurnal Manajemen Teori dan Terapan | Tahun 2, No.1, April 2009 | Nanis Susanti 